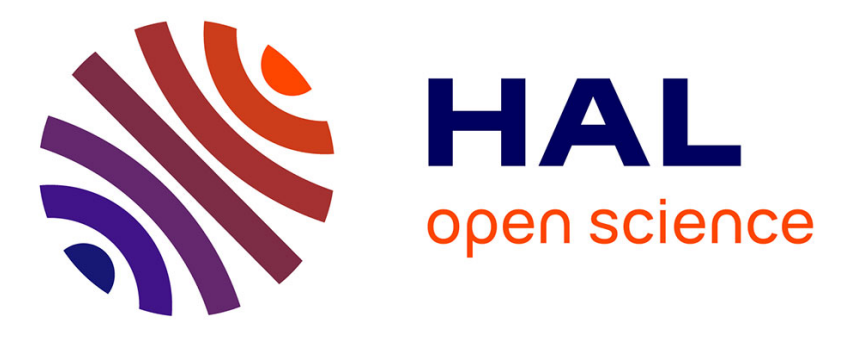

\title{
Using Microwave Soil Heating to Inhibit Invasive Species Seed Germination
}

Mélissa de Wilde, Elise Buisson, Nicole Yavercovski, Loic Willm, Livia Bieder, Francois Mesleard, Mélissa de Wilde, François Mesléard

\section{- To cite this version:}

Mélissa de Wilde, Elise Buisson, Nicole Yavercovski, Loic Willm, Livia Bieder, et al.. Using Microwave Soil Heating to Inhibit Invasive Species Seed Germination. Invasive Plant Science and Management, 2017, 10 (3), pp.262-270. 10.1017/inp.2017.29 . hal-01681631

\section{HAL Id: hal-01681631 \\ https://hal.science/hal-01681631}

Submitted on 4 May 2018

HAL is a multi-disciplinary open access archive for the deposit and dissemination of scientific research documents, whether they are published or not. The documents may come from teaching and research institutions in France or abroad, or from public or private research centers.
L'archive ouverte pluridisciplinaire HAL, est destinée au dépôt et à la diffusion de documents scientifiques de niveau recherche, publiés ou non, émanant des établissements d'enseignement et de recherche français ou étrangers, des laboratoires publics ou privés. 


\title{
Using Microwave Soil Heating to Inhibit Invasive Species Seed Germination
}

\section{Mélissa De Wilde, Elise Buisson, Nicole Yavercovski, Loïc Willm, Livia Bieder and François Mesleard*}

First, second and sixth authors: Post-doctoral Researcher, Associate professor, and Professor, Institut Méditerranéen de Biodiversité et d'Ecologie (IMBE), UMR CNRS 7263/IRD 237 Université d'Avignon et des Pays de Vaucluse, Aix Marseille Université, IUT d'Avignon, 337 chemin des Meinajaries Site Agroparc BP 61207, F-84911 Avignon cedex 09, France; Third, fourth, fifth and sixth authors: Research Assistant, Research Assistant, Student and Senior Researcher, Institut de Recherche de la Tour du Valat, Le Sambuc, F-13200 Arles, France. Corresponding author's E-mail: melissa.de-wilde@outlook.com

\begin{abstract}
Successful long-term invasive plant eradication is rare. The methods target only the adult stage, not taking into account plant development capacities from a large seed bank. Heating by microwave has been considered because it offers a means to quickly reach the temperature required for the loss of seed viability and therefore inhibit germination. Previous results were not encouraging because homogenous and deep penetration of the waves was not achieved and the various parameters that can modify the effectiveness of treatment were rarely properly addressed as a whole. The aim of this study was to determine, under experimental conditions, the best microwave treatment to inhibit invasive species seed germination, in terms of power (2, 4, $6 \mathrm{~kW})$ and duration (2, 4, $8 \mathrm{~min})$ of treatments, and depending on the soil moisture $(10,13,20,30 \%)$ and seed depth in the soil $(2,12 \mathrm{~cm})$. This was tested on 3 invasive species: Bohemian knotweed, giant goldenrod and jimsonweed. The most effective treatments required relatively high power and duration $(2 \mathrm{~kW} 8 \mathrm{~min}, 4 \mathrm{~kW} 4 \mathrm{~min}, 6 \mathrm{~kW} 2 \mathrm{~min}$ and $6 \mathrm{~kW} 4 \mathrm{~min}$; $4 \mathrm{~kW} 8 \mathrm{~min}$ and $6 \mathrm{~kW} 8 \mathrm{~min}$ were not tested for technical reasons), and their effectiveness diminished with increasing soil moisture: germination percentage between 0 and $2 \%$ for the lowest soil moisture and between 0 and $56 \%$ for the intermediate soil moisture compared with germination percentage between 27 and $68 \%$ in control treatments while for the highest soil moisture, only $2 \mathrm{~kW} 8 \mathrm{~min}$ and $4 \mathrm{~kW} 4 \mathrm{~min}$ lowered germination percentage between 2 and $19 \%$. In some cases, the germination of seeds located at $12 \mathrm{~cm}$ depth during treatment was more strongly affected. Seeds of giant goldenrod were the most sensitive, probably due to their small size. Results are sufficiently encouraging to justify further experiments to determine the most effective treatments that would be applied following development of a microwave device to treat large volumes of soil infested by invasive seed efficiently and with reasonable energy requirements . Other types of soil, in terms of texture and organic matter content, should also be tested in future experiments because they influence soil water content and consequently microwave heating.
\end{abstract}

Nomenclature: Bohemian knotweed, Fallopia $\times$ bohemica (Chrtek and Chrtková) J. Bailey; giant goldenrod, Solidago gigantea Aiton; jimsonweed, Datura stramonium L.

Key Words: Invasive plant species, microwave heating, seed bank, germination inhibition, soil moisture, seed depth, power, duration 


\section{Management Implications}

Alien plant species often show a strong vegetative (e.g. rhizomes) and sexual (seeds) reproductive capacity, which together represent dispersal and resistance organs contributing to species invasiveness and affecting native community. However, seeds are the most highly resistant organs of plants, and preventing their germination from the seed bank impedes a species to recruit individuals and thus to persist in a community, but this is often underestimated. Inhibition of invasive seed bank germination relied on the use of a variety of methods and their combination which involve a range of constraints and are often not wholly effective. New and innovative methods for rapidly inhibiting invasive seed bank germination need to be explored to treat contaminated soil in situ in different ecosystem types (croplands, natural environments or construction sites). Heating by microwave has been considered because it offers a means to quickly reach the temperature required for the loss of seed viability and therefore inhibit germination. In order to determine the technical characteristics of a mobile continuous conveying tunnel with microwave equipment allowing the treatment of infested soil in situ, we carried out two experiments under laboratory controlled conditions. Our results showed that treatments $2 \mathrm{~kW} 8 \mathrm{~min}$ and $4 \mathrm{~kW} 4 \mathrm{~min}$, requiring about $3.05 \mathrm{kWh} . \mathrm{m}^{-2}\left(1097 \mathrm{~J} . \mathrm{cm}^{-2}\right)$, allowed the relatively efficient inhibition of seed germination under different soil moisture levels (10 to $31.4 \%$ ) and down to a depth of $12 \mathrm{~cm}$, making this equipment potentially suitable for treating larger soil volumes compared to other equipment described in the various existing works. The use of microwave systems to inhibit rapidly and fully the invasive seed bank germination is promising, and today may be one of the most effective methods available. Results are sufficiently encouraging to justify further experiments to determine the most effective treatments that would be applied following development of a microwave device to treat large volumes of soil infested by invasive seed efficiently and with reasonable energy requirements. Other types of soil, in terms of texture and organic matter content, should be tested in future experiments because they influence soil water content and consequently microwave heating.

\section{Introduction}

Invasive plant control and eradication measures (Hulme 2006) have relied on the use of a variety of methods and their combination (manual and mechanical removal, chemical control with herbicide use or biological controls; e.g. Beerling 1990; Boss et al. 2007; Atkins and Williamson 2008; Derr 2008). These operations are time-consuming and expensive and usually have i) time-limited effect on target invasive plant species, and ii) a potential impact on nontarget native species and other ecosystem components (Kettenring and Reinhardt Adams 2011). This can be partly explained by the fact that the methods target only the adult stage and do not take into account the plant development capacities from a large propagule bank (Regan et al. 2006; Richardson and Kluge 2008).

Alien plant species often show a strong vegetative (e.g. rhizomes) and sexual (seeds) reproductive capacity, which together represent dispersal and resistance organs contributing to species invasiveness and affecting native community invasibility and viability (Gioria et al. 2012). However, seeds are the most highly resistant organs of plants, and preventing their germination from the seed bank impedes a species to recruit individuals and thus to persist in a community (Regan et al. 2006; Richardson and Kluge 2008), but this is often underestimated. A possible method to inhibit invasive plant seed germination is the extraction of contaminated soils, which is not without risk due to possible contamination during transport, followed by soil solarization which involves a range of constraints, such as suitable weather conditions, setting land aside, duration of treatment and is often not wholly effective (Cohen and Rubin 2007). An 
alternative option for depleting the invasive seed bank is to limit seed production by implementing a control method (e.g. herbicides, fire; Richardson and Kluge 2008) immediately after seedling emergence, either by promoting seed bank emergence (e.g. by soil tillage and/or irrigation; Benvenuti and Macchia 2006) or by exploiting the difference in germination phenology, if it exists, between native and alien species (Marushia et al. 2010; Wolkovich and Cleland 2011). However, both methods represent a control method which is not applicable in the natural environment where the remaining seed bank is sensitive to natural disturbances and where long-term eradication requires the repetition of the operations over several years (Benvenuti and Macchia 2006; Richardson and Kluge 2008; Marushia et al. 2010). Consequently, new and innovative methods for rapidly inhibiting invasive soil seed bank germination need to be explored to treat contaminated soil in situ in different ecosystem types (croplands, natural environments or construction sites).

Some studies have considered the potential of the microwave to control invasive and pest species for commercial, agricultural or ecological purposes, in particular in the interests of developing non-chemical techniques (Barker and Craker 1991; Fleming et al. 2005; Sahin and Saglam 2015; Ambrose et al. 2015). Microwave radiation causes dielectric heating of moist materials and offers the means to rapidly reach the temperature needed for loss of seed viability and inhibition of germination (in a $60-90^{\circ} \mathrm{C}$ range, depending on the authors; Barker and Craker 1991; Mavrogianopoulos et al. 2000; Bebawi et al. 2007; Brodie et al. 2007a; Sahin 2014), and can be considered as a thermal weed control method that has no direct environmental drawbacks, especially as there is no residue to contaminate the surroundings, unlike herbicides - The results have generally not been encouraging for the development of these microwave treatments, either in terms of lack of effectiveness, or because of the excessive costs that this method generates. However, the cited studies used microwave equipment which did not enable the homogenous and deep penetration of the waves (e.g. frequency of $2450 \mathrm{MHz}$, only one generator, static batch, horn antenna). The commonly used pyramidal horn antenna led to nonhomogeneous vertical and horizontal temperature distribution in the soil, with a peak temperature (around $90^{\circ} \mathrm{C}$ ) occurring between 2 and $5 \mathrm{~cm}$ below the soil surface along the center line of the horn antenna, making this equipment effective in inhibiting seeds germination only at low depths along the center line of the horn antenna (Bebawi et al. 2007). Furthermore, the different parameters that can limit or enhance the treatment's effectiveness (soil moisture, power, duration) were rarely addressed satisfactorily as a whole (Barker and Craker 1991; Bebawi et al. 2007). Previous studies showed that seed mortality was greater in moist soil rather than dry soil (Bebawi et al. 2007; Brodie et al. 2007a). However, they used sand that has the lowest dielectric constant and does not allow testing of the effect of high soil moisture on microwave treatment efficiency. Although moisture is needed to cause and transfer heat, higher moisture content may require higher treatment power and/or duration to inhibit seed germination (Mavrogianopoulos et al. 2000, Brodie et al. 2007b).

The aim of this study was thus to assess, under experimental conditions, the most effective combination of power and duration to inhibit the seed germination of invasive plant species when treating soil with microwave, taking into account soil moisture and the depth of seeds in the soil. We tested the effect of microwave treatments on the germination capacity of seeds of three invasive species widespread in Europe (Datura stramonium L., Fallopia $\times$ bohemica (Chrtek and Chrtková) J. Bailey and Solidago gigantea Aiton; Pyšek et al. 2009). Effective treatments correspond to treatments inhibiting all seed germination, thus preventing any germination that could lead to a new invasion. The results of this work, carried out under laboratory controlled conditions, will subsequently determine the technical characteristics of a continuous conveying tunnel with microwave equipment allowing the treatment of infested soil collected in situ. The present work is included in the project P.A.R.I.S ("Process Accéléré de Réduction des espèces InvasiveS") attempting to develop a process prototype to locally 
eradicate invasive plant species using microwave radiations. The process consists of heating large quantities of soil infested with invasive plant species (vegetative parts and seeds) in situ, with a mobile microwave oven. The project is led by a consortium of companies specialized in renaturation, civil engineering, microwaves, energy supply and research laboratories.

\section{Material and Methods}

Biological Material. The experiments were performed on seeds from three invasive plant species that have the specific feature of producing a large number of seeds and are widely available in Europe.

Datura stramonium (Solanaceae) is an annual herb that persists in cropping systems and disturbed areas (Weaver and Warwick 1984; Kleyer et al. 2008). Its region of origin is America and Mexico is an major center of diversity of the genus (Symon and Haegi 1991). The fruits are thorny capsules up to $4 \mathrm{~cm}$ in length and may contain up to 650 kidney-shaped seeds (van Kleunen et al. 2007) of 3-4 mm long, 2-3 mm wide and 8.7-10.7 mg (Kleyer et al. 2008).

Fallopia $\times$ bohemica (Polygonaceae) is a perennial herb resulting from the hybridization between Fallopia japonica (Houtt.) Rons Decr and Fallopia sachalinensis (F. Schmidt) Rons Decr and the resulting backcrosses with the parent species, both native to Asia. These plants thrive in alluvial areas and the banks of rivers where moisture and nutrient rich substrates enable it to achieve optimal growth, leading to single-species stands, but it is also found in ruderal environments such as road sides and abandoned land (Beerling et al. 1994). The seeds are carried by achenes 2-4 mm long and $2 \mathrm{~mm}$ wide (Beerling et al. 1994).

Solidago gigantea (Asteraceae), native to North America, is a perennial herb and a major invader, often forming dense monospecific stands. Although $S$. gigantea prefers rich and rather moist soils, it occurs over a wide range of soil fertility and texture conditions. It is most vigorous in ruderal and riverside habitats, but also grows at drier sites, such as road sites and embankments (Weber and Jakobs 2005). The branches contain numerous flower heads (1200 \pm 190, Schmid et al. 1988) producing abundant pubescent achenes $1-1.8 \mathrm{~mm}$ in length and 0.06$0.074 \mathrm{mg}$ in weight, with long hairs so that they are readily dispersed in the wind (Weber and Jakobs, 2005; Kleyer et al. 2008).

Achenes of Fallopia $\times$ bohemica and Solidago gigantea were collected in March 2015 along the Isère River in Savoie (France). Seeds of Datura stramonium were collected in October 2014 from D. stramonium stands growing along Rhône River in the Drôme (France). The achenes and seeds were collected randomly from 10 individuals of the same population and then pooled. The achenes and seeds were stored under dry conditions at room temperature until they were used for experiments. Previous works showed that these storage conditions for short amount of time (as in this experiment) do not affect achene and seed viability and the germination capacity of species used (Benvenuti and Macchia 1997; Engler et al. 2011; Bochenek et al. 2016). In the rest of the manuscript, only the term 'seed' will be used.

Microwave System. The AMW200 batch microwave system (SAIREM SAS, Neyron, France, $\mathrm{http}: / / \mathrm{www}$. sairem.com) used in this study is designed for testing purposes, not for industrial use. The results obtained with this equipment will subsequently determine the technical characteristics of a continuous conveying tunnel with microwave equipment, designed for the treatment of infested soil collected in situ.

The $304 \mathrm{~L}$ microwave oven is a stainless steel chamber which can contain a $600 \mathrm{x} 400 \mathrm{x}$ $250 \mathrm{~mm}$ block maximum size and $30 \mathrm{~kg}$ maximum weight. The microwave system is equipped with a polyethylene sliding table with a 840 x $620 \mathrm{~mm}$ usable surface and a pneumaticallydriven sliding door, making easier block loading/unloading. The microwave system operates at 
$915 \mathrm{MHz}$ which is more penetrating and allows the treatment of thicker products (up to $25 \mathrm{~cm}$ ) compared to the frequently used $2450 \mathrm{MHz}$ microwave frequency (approximately 3 times higher). Heating homogeneity is achieved by the use of microwave coupling from the top and bottom of the product as well as the rotation of a turntable. The output power of $10 \mathrm{~kW}$ maximum is produced by $2 \times 5 \mathrm{~kW}$ generators (magnetron) and is adjustable from $1 \mathrm{~kW}$ to $10 \mathrm{~kW}$. The system is water-cooled.

Experimental Design. Microwave Treatments. The study was subdivided into two experiments. Experiment 1. The aim of this experiment, conducted on April 13, 2015, was to assess the most effective combination of power $\times$ duration to inhibit the germination of the three target species seeds, buried at two depths, when treating soil by microwave.

The experiment was carried out on samples of $8 \mathrm{~kg}$ of soil each contained in a cardboard box $(35 \times 25 \times 15 \mathrm{~cm})$ covered on the bottom and sides with plastic bubble wrap to prevent water vapor emanating from the soil from softening the cardboard and significantly complicating handling. The topsoil used was collected on a wooded slope (Gard, France), and consisted of a sandy loam soil ( $55.5 \%$ sand, $31 \%$ silt and $13.5 \%$ clay; according to USDA soil classification).

The seven treatments (power $\times$ duration combinations) used for this experiment (Table S1) were determined through tests and soil temperature measurements at the periphery and in the middle of the soil with mercury thermometers immediately after microwave tests in a replicate for each test. The pre-treatment soil temperature was $14.7^{\circ} \mathrm{C}$ and soil moisture (defined as mass water content and expressed as a percentage $=([$ wet soil mass - dry soil mass $] /$ dry soil mass)*100) was $13.5 \% \pm 4.4\left(\mathrm{H}_{\exp 1}\right)$. Homogeneous temperatures equal to or higher than $90^{\circ} \mathrm{C}$,considered as a temperature needed for the loss of seed viability and thus inhibition of seed germination (Barker and Craker 1991), were achieved by four power $\times$ duration combinations (Table S1), for which we assume no post-treatment germination will be observed. To define the lower limits of effectiveness, three other combinations of these powers and durations were performed (Table S1). For safety reasons (formation of electric arcs within the cavity with a high risk of magnetron damage), higher treatments could not be performed (4kW8min and 6kW8min).

For each species, two bags containing 20 seeds were placed in each cardboard box containing soil. Baking paper bags were used to keep the seeds in place during the experiment and to easily extract the seeds from the soil after treatment. In order to assess the effect of seed burial in the soil, one seed bag was placed at $2 \mathrm{~cm}$ depth (top) and the others at $12 \mathrm{~cm}$ depth (bottom). There were five replicate boxes per treatment.

The control treatment consisted of bags, containing 20 seeds of each species, to which no microwave treatment was applied. To allow comparison of different microwave treatments with the control treatment, 5 bags of control treatments were randomly distributed at each depth.

The content of each bag (20 seeds) was stuck to double-face plastic films, themselves stuck on tissues (Diatex), which were permeable to $0.2 \mathrm{~mm}$, and placed on a Petri dish $(6 \mathrm{~cm}$ diameter) on cotton soaked in distilled water. Petri dishes were placed in a growth chambers (Hotcold-GL: $12 \mathrm{~K}$ lux) with temperature controlled at $25^{\circ} \mathrm{C}$ day $/ 15^{\circ} \mathrm{C}$ night and a photoperiod of $14 \mathrm{~h}$ day/ $10 \mathrm{~h}$ night. Seed germination was monitored every two days, with counting and uprooting of seedling as they germinate to avoid preemption phenomena that could prevent germination of other individuals. The germinations were monitored until no germination was observed, corresponding to 44 days.

The effect of microwave treatment (seven power $\times$ duration combinations and control), depth (two) and species (three) and their interaction on germination percentage was tested using logistic regression (binary data). When a significant effect was observed, post hoc comparisons of means were conducted with a Tukey's test. All statistical tests were done using R software (The R Foundation for Statistical Computing, version 3.2.0). 
Three other parameters were assessed to study the effect of microwave treatment on

\section{Results}

Experiment 1. Germination percentage was significantly affected by the microwave treatment $\times$ depth $\times$ species interaction (Table 1 ). S. gigantea showed a significantly higher germination percentage than D. stramonium and $F . \times$ bohemica in the control treatment, whatever the depth (Fig 1). Germination percentage was between 0 and $1 \%$ for treatments $2 \mathrm{~kW} 8 \mathrm{~min}, 4 \mathrm{~kW} 4 \mathrm{~min}$, $6 \mathrm{~kW} 2 \mathrm{~min}$ and $6 \mathrm{~kW} 4 \mathrm{~min}$ for all the species, whatever the depth, and significantly lower compared to treatments $2 \mathrm{~kW} 2 \mathrm{~min}, 2 \mathrm{~kW} 4 \mathrm{~min}, 4 \mathrm{~kW} 2 \mathrm{~min}$ and control (Table 1, Fig 1). For $D$. stramonium and $F . \times$ bohemica, $2 \mathrm{~kW} 2 \mathrm{~min}, 2 \mathrm{~kW} 4 \mathrm{~min}$ and $4 \mathrm{~kW} 2 \mathrm{~min}$ treatments had no effect on germination percentage compared to the control treatment, whatever the depth (Table 1, Fig 1). For $S$. gigantea, $2 \mathrm{~kW} 2 \mathrm{~min}$ treatment had no effect on germination percentage, whatever the depth; $2 \mathrm{~kW} 4 \mathrm{~min}$ treatment significantly reduced germination percentage of seeds located at a $12 \mathrm{~cm}$ depth only, and $4 \mathrm{~kW} 2 \mathrm{~min}$ treatment significantly lowered germination percentage particularly for seeds located at a $2 \mathrm{~cm}$ depth, compared to control treatment (Table 1, Fig 1). 
Experiment 2. Mass water content differed significantly between the three moisture levels tested in Experiment 2 and moisture of soil used in Experiment $1\left(\mathrm{H}_{\exp 1} ; F^{3}{ }_{80}=196.2, P<0.001\right)$, with $\mathrm{H} 1=10.2 \% \pm 2.6<\mathrm{H}_{\exp 1}=13.5 \% \pm 4.4<\mathrm{H} 2=20.4 \% \pm 1.6<\mathrm{H} 3=31.4 \% \pm 2.4$ (mean \pm SE, post-hoc Tukey's test, $P<0.005$ ).

Germination percentage was affected by the species $\times$ depth $\times$ microwave treatment interaction, by the species $\times$ depth $\times$ moisture interaction and by the depth $\times$ microwave treatment $\times$ moisture interaction (Table 2 ).

$S$. gigantea showed a higher germination percentage than $D$. stramonium and $F . \times$ bohemica in the control treatment, whatever the depth (microwave treatment $\times$ depth $\times$ species interaction, post-hoc Tukey's test, $P<0.05$; Table 2, Fig 2).

For $\mathrm{H} 1$, germination percentage was between $0 \%(D$. stramonium and $F . \times$ bohemica $)$ and $2 \%(S$. gigantea) for the four tested microwave treatments $(4 \mathrm{~kW} 2 \mathrm{~min}, 4 \mathrm{~kW} 4 \mathrm{~min}, 2 \mathrm{~kW} 8 \mathrm{~min}$ and $2 \mathrm{~kW} 4 \mathrm{~min}$ ), whatever the depth, and were significantly lower compared to control treatment (Table 2, Fig 2). For H2, the four microwave treatments significantly lowered the germination percentage (germination percentage between 0 and 56\%), whatever the depth, compared to control treatment (germination percentage between 36 and 68\%; Table 2, Fig 2). For seeds located at $12 \mathrm{~cm}$ depth, germination percentage did not differ between microwave treatments, but for seeds located at $2 \mathrm{~cm}$ depth, $4 \mathrm{~kW} 4 \mathrm{~min}, 2 \mathrm{~kW} 8 \mathrm{~min}$ and $2 \mathrm{~kW} 4 \mathrm{~min}$ treatments reduced germination percentage more than $4 \mathrm{~kW} 2 \mathrm{~min}$. For $\mathrm{H} 3$, only $2 \mathrm{~kW} 8 \mathrm{~min}$ and $4 \mathrm{~kW} 4 \mathrm{~min}$ significantly lowered germination percentage (germination percentage between 2 and 19\%), whatever the depth, compared to control treatment.

\section{Discussion}

Effective treatments to inhibit invasive plant seed germination were, as expected, the power $\times$ duration combinations enabling soil to reach $90^{\circ} \mathrm{C}$ (Bebawi 2007; Brodie et al. 2007a). In some cases, a temperature equal to or higher than $90^{\circ} \mathrm{C}$ does not completely inhibit the germination of the seeds and allows 1 or $2 \%$ germination. This may be due to uneven temperature distribution in the soil, as sometimes observed between the center and the periphery. Even if the characteristics of the oven favor the good distribution of the waves, the use of a cavity may mean that certain zones receive more energy than others (hotspots). The treatments $2 \mathrm{~kW} 4 \mathrm{~min}$ and $4 \mathrm{~kW} 2 \mathrm{~min}$ showed a strong depth effect at $\mathrm{H} 2$, which could be due to the use of a cardboard box for the experiments, leading to energy loss in the open part of the box compared to the closed bottom. Cooling near the surface prevented sufficient heating to kill seeds in the top $2 \mathrm{~cm}$ of soil (Barker and Craker 1991). These results would be different with equipment that does not use a cavity (open structure microwave applicator) or cardboard box.

The capacity of microwave to enable soil to reach $90^{\circ} \mathrm{C}$ and to totally inhibit seed germination decreased with increasing soil moisture in the range tested. Treatments $2 \mathrm{~kW} 4 \mathrm{~min}$, $2 \mathrm{~kW} 8 \mathrm{~min}, 4 \mathrm{~kW} 2 \mathrm{~min}$ and $4 \mathrm{~kW} 4 \mathrm{~min}$ were all effective at the lower soil moisture level $(\mathrm{H} 1=$ $10.2 \% \pm 2.6$ ), but treatments $2 \mathrm{~kW} 4 \mathrm{~min}$ and $4 \mathrm{~kW} 2 \mathrm{~min}$ became ineffective at higher soil moisture levels $\left(\mathrm{H}_{\exp 1}=13.5 \% \pm 4.4, \mathrm{H} 2=20.4 \% \pm 1.6\right.$ and $\left.\mathrm{H} 3=31.4 \% \pm 2.4\right)$; and treatments $2 \mathrm{~kW} 8 \mathrm{~min}$ and $4 \mathrm{~kW} 4 \mathrm{~min}$ remained effective even if their effectiveness tended to decrease at the highest soil moisture level (H3). The more water in the soil, the more energy is needed to achieve the same temperature for a sufficient amount of time to inhibit germination: when the moisture level is higher, a longer processing time and/or higher power are required (Mavrogianopoulos 2000; Fleming et al. 2005). However, this trend may be reversed with very 
dry or sandy soils that do not allow water retention, because in the absence of water in the soil, microwave treatment does not cause heating. Other types of soil, in terms of texture and organic matter content, should also be tested in future experiments because they influence soil water content and consequently microwave heating (Brodie et al. 2007a). A temperature of $90^{\circ} \mathrm{C}$ may be considered necessary for the loss of seed viability and thus inhibition of seed germination (Barker and Craker 1991). However, the question of how long the treatments should last for the soil to reach this temperature and how long the seeds must undergo this temperature to achieve germination inhibition remains. The treatment $2 \mathrm{~kW} 8 \mathrm{~min}$ at the highest moisture level reached a temperature of $90^{\circ} \mathrm{C}$ but did not damage all the seeds. This may be because at high moisture levels, the time required to reach $90^{\circ} \mathrm{C}$ is longer and therefore the seeds have undergone this temperature over a shorter duration. Braker and Craker (1991) showed that at least 120s were required to heat the soil above $80^{\circ} \mathrm{C}$ and that a $30 \mathrm{~s}$ period of temperatures above $80^{\circ} \mathrm{C}$ is sufficient to kill seeds.

The species $S$. gigantea presented the highest germinating capacity but also seems to show the most sensitivity to the tested microwave treatments, which may be due to the small size of its seeds (achenes of 1-1.8 mm length, Weber and Jakobs 2005; seed mass of 0.06-0.074 mg, Kleyer et al. 2008) that could make it more susceptible to microwave heating. Seed size seems to be a determining factor to explore further, as our results were not consistent with those of other studies, suggesting that seeds with a higher mass are more susceptible to microwave treatment, perhaps because larger seeds present a larger 'radar cross section' propagating microwave, and thus a higher capacity to absorb electromagnetic energy (Bebawi et al. 2007). Studies on seeds with more contrasting morphologies could shed light on this point.

Microwave soil treatment could potentially be the only method to rapidly and fully inhibit the soil seed bank germination in different types of environments. A major obstacle prohibiting its use is the large amount of energy required to obtain satisfactory results. Our results showed that treatments $2 \mathrm{~kW} 8 \mathrm{~min}$ and $4 \mathrm{~kW} 4 \mathrm{~min}$, requiring about $3.05 \mathrm{kWh} . \mathrm{m}^{-2}\left(1097 \mathrm{~J} . \mathrm{cm}^{-2}\right)$, allowed the relatively efficient inhibition of seed germination under different soil moisture levels (10 to $31.4 \%$ ) and down to a depth of $12 \mathrm{~cm}$, making this equipment potentially suitable for treating larger soil volumes compared to other equipment described in the various existing experimental works. Mavrogianopoulos et al. (2000) used an open microwave equipment with the waveguide placed vertically on the soil, which required between 7.4 and $24 \mathrm{kWh} \cdot \mathrm{m}^{-2}$ (depending on soil moisture: 5.5 or $15 \%$, and initial soil temperature: 20 or $40^{\circ} \mathrm{C}$ ) to reach only $61^{\circ} \mathrm{C}$ at $10 \mathrm{~cm}$ depth in fine sandy loam soil. Brodie et al. (2007b), with a pyramidal horn antenna as a microwave applicator in the soil, report an energy requirement of $0.63 \mathrm{kWh} . \mathrm{m}^{-2}$ to inhibit seed germination (germination percentage of $2.5 \%$ ) in air dried-soil at only $3 \mathrm{~cm}$ depth, while it does not allow inhibition of seed germination (germination percentage of $100 \%$ ) in soil with $37 \%$ moisture. According to the results available in Brodie et al. (2007b), 1.875kWh.m ${ }^{-2}$ would be necessary to totally inhibit seed germination (germination percentage of $0 \%$ ) in moist soil at 3 $\mathrm{cm}$ depth. The experiments of Brodie and Hollins (2015) with horn antenna showed that 3528 $\mathrm{J} . \mathrm{cm}^{-2}$ was not sufficient to totally inhibit germination in dry sand, whatever the depth, and 1176 $\mathrm{J} . \mathrm{cm}^{-2}$ and $2352 \mathrm{~J} . \mathrm{cm}^{-2}$ were required to inhibit germination at $5 \mathrm{~cm}$ and $10 \mathrm{~cm}$ respectively in sand with $20 \%$ moisture. In loam soil (unknown moisture level), a horn antenna applying 1020 $\mathrm{J} . \mathrm{cm}^{-2}$ does not allow total inhibition of seed germination, even at low depth (germination percentage of $1.6 \%$ at $2 \mathrm{~cm}$ burial depth, Brodie and Hollins 2015), while our equipment required only $1097 \mathrm{~J} . \mathrm{cm}^{-2}$ and enabled treatment of larger soil volumes. In view of the results obtained and in comparison with the experimental work using open microwave equipment placed directly on the soil surface, the development of a mobile continuous conveying tunnel with microwave equipment used in this study will be considered in order to treat infested soil in situ. However the use of this equipment will require to excavate soil and fed it into the tunnel 
which involves additional energy costs which must be quantified in future work with a field prototype.

The use of microwave systems to inhibit the invasive species seed bank germination is promising, and today may be one of the most effective methods available. Results are encouraging enough to justify further experiments to determine the most effective treatments depending on environmental conditions (e.g. types of soil) in order to develop a microwave device to treat efficiently and with reasonable energy requirements large volumes of soil infested by invasive seed bank. However, this technique is not selective and result in the depletion of the entire seed bank, native species included, and may alter the soil conditions through its effect on soil organisms and their activities. Few studies have considered the impact of microwave treatments on soil invertebrates, but Rahi and Rich (2011) showed their lethal effect on a nematodes species. Responses of key soil micro-organisms and the functional consequences are rather more extensively documented, but results may be contradictory. While some authors demonstrated that fungi are more susceptible than bacteria (Wainwright et al. 1980; Speir et al. 1986), Brodie et al. 2015 observed no responses of soil fungi, ciliates, amoeba and flagellates, and a decrease in the bacterial population. (Brodie et al. 2015). Cooper and Brodie (2009) showed little to no effect of microwave treatment on key soil nutrients and $\mathrm{pH}$, while others showed that soil nutrient content may be modified due to micro-organism cell lyse or the modification of processes due to temperature increase (Wainwright et al. 1980; Speir et al. 1986; Brodie et al. 2015). These questions therefore remain to be explored for the purposes of the management and restoration of ecosystems affected by biological invasions, as they could influence native and alien plant recruitment and development.

\section{Acknowledgements}

This work is part of an FUI (Single Interministerial Fund) research and development project, co-financed by BPI France, Provence Alpes Côte d'Azur (PACA) and Languedoc Roussillon Regions and the Ain local authority. In addition to the authors, the participants in this project also include scientists from EDF, GECO Ingénierie et Travaux, LST\&M, NGE, SAIREM. No conflicts of interest have been declared.

\section{Literature Cited}

Ambrose A, Lee W-H, Cho B-K (2015) Effect of microwave heat treatment on inhibition of corn seed germination. J Biosyst Eng 40:224-231

Atkins EO, Williamson PS (2008) Comparison of four techniques to control elephant ear. J Aquat Plant Manage 46:158-162

Barker AV, Craker LE (1991) Inhibition of weed seed germination by microwaves. Agron J 83:302-305

Bebawi FF, Cooper AP, Brodie GI, Madigan BA, Vitelli JS, Worsley KJ, Davis KM (2007) Effect of microwave radiation on seed mortality of rubber vine (Cryptostegia grandiflora R.Br.), parthenium (Parthenium hysterophorous L.) and bellyache bush (Jatropha gossypiifolia L.). Plant Prot Q 22:136-142 
Beerling DJ (1990) The use of non- persistent herbicides, glyphosate, and 2, 4- D amine, to control riparian stands of Japanese knotweed (Reynoutria japonica Houtt.). River Res Appl 5:413-417

Beerling DJ, Bailey JP, Conolly AP (1994) Fallopia japonica (Houtt.) Ronse Decraene. J Ecol 82:959-979

Benvenuti S, Macchia M (1997) Light environment, phytochrome and germination of Datura stramonium L. seeds. Environ Exp Bot 38:61-71

Benvenuti S, Macchia M (2006) Seedbank reduction after different stale seedbed techniques in organic agricultural systems. Ital J Agron 1:11-22

Bochenek A, Synowiec A, Kondrat B, Szymczak M, Lahuta LB, Gołaszewski J (2016) Do the seeds of Solidago gigantea Aiton have physiological determinants of invasiveness? Acta Physiol Plant 38:1-11

Boss D, Schläpfer E, Fuchs J, Défago G, Maurhofer M (2007) Improvement and application of the biocontrol fungus Stagonospora convolvuli LA39 formulation for efficient control of Calystegia sepium and Convolvulus arvensis. J Plant Dis Protect 114:232-238

Brodie G, Pasma L, Bennett H, Harris G, Woodworth J (2007a) Evaluation of microwave soil pasteurization for controlling germination of perennial ryegrass (Lolium perenne) seeds. Plant Prot Q 22:150-154

Brodie G, Botta C, Woodworth J (2007b) Preliminary investigation into microwave soil pasteurization using wheat as a test species. Plant Prot Q 22:72-75

Brodie G, Hollins E (2015) The effect of microwave treatment on ryegrass and wild radish plants and seeds. Glob J Agric Innov Res Dev 2:16-24

Brodie G, Grixti M, Hollins E, Cooper A, Li T, Cole M (2015) Assessing the impact of microwave treatment on soil microbial populations. Glob J Agric Innov Res Dev 2:25-32

Cohen O, Rubin B (2007) Soil Solarization and Weed Management. Pages 177-200 in Nonchemical Weed Management. Upadhyaya MK, Blackshaw RE eds.

Cooper A \& Brodie G (2009) The effect of microwave radiation and soil depth on soil pH, N, $\mathrm{P}, \mathrm{K}, \mathrm{SO}_{4}$ and bacterial colonies. Plant Prot Q 24:67-70

Derr JF (2008) Common reed (Phragmites australis) response to mowing and herbicide application. Invas Plant Sci Mana 1:12-16

Engler J, Abt K, Buhk C (2011) Seed characteristics and germination limitations in the highly invasive Fallopia japonica s.1. (Polygonaceae). Ecol Res 26:555-562

Fleming MR, Janowiak JJ, Halbrendt JDKJM, Miller LSBDL, Hoover K (2005) Efficacy of commercial microwave equipment for eradication of pine wood nematodes and cerambycid larvae infesting red pine. Forest Prod J 55:226-232

Gioria M, Pyšek P, Moravcová L (2012) Soil seed banks in plant invasions: promoting species invasiveness and long-term impact on plant community dynamics. Preslia 84:327-350

Hulme PE (2006) Beyond control: wider implications for the management of biological invasions. J Appl Ecol 43:835-847

Kettenring KM, Reinhardt Adams C (2011) Lessons learned from invasive plant control experiments: a systematic review and meta- analysis. J Appl Ecol 48:970-979

Kleyer M, Bekker RM, Knevel IC, Bakker JP, Thompson K, Sonnenschein M, Poschlod P, van Groenendael JM, Klimeš L, Klimešová J, Klotz S, Rusch GM, Hermy M, Adriaens D, Boedeltje G, Bossuyt B, Dannemann A, Endels P, Götzenberger L, Hodgson JG, Jackel AK, Kühn I, Kunzmann D, Ozinga WA,.Römermann C, Stadler M, Schlegelmilch J, Steendam HJ, Tackenberg O, Wilmann B, Cornelissen JHC, Eriksson O, Garnier E, Peco B (2008) The LEDA Traitbase: a database of life- history traits of the Northwest European flora. J Ecol 96:1266-1274

Marushia RG, Cadotte MW, Holt JS (2010) Phenology as a basis for management of exotic annual plants in desert invasions. J Appl Ecol 7:1290-1299 
Mavrogianopoulos GN, Frangoudakis A, Pandelakis J (2000) Energy efficient soil desinfestation by microwaves. J Agr Eng Res 75:149-153

Pyšek P, Lambdon PW, Arianoutsou M, Kühn I, Pino J, Winter M (2009) Alien vascular plants of Europe. Pages 43-61 in Handbook of alien species in Europe. Springer Netherlands.

Rahi GS, Rich JR (2011) Effect of moisture on efficiency of microwaves to control plantparasitic nematodes in soil. J Microwave Power EE 45:86-93

R Core Team (2015) R A language and environment for statistical computing. R Foundation for Statistical Computing, Vienna, Austria. URL http://www.R-project.org/.

Regan TJ, McCarthy MA, Baxter PWJ, Panetta FD, Possingham HP (2006) Optimal eradication: when to stop looking for an invasive plant. Ecol Lett 9:759-766

Richardson DM, Kluge RL (2008) Seed banks of invasive Australian Acacia species in South Africa: role in invasiveness and options for management. Perspect Plant Ecol 10:161-177

Sahin H (2014) Effects of microwaves on the germination of weed seeds. J Biosyst Eng 39:304309

Sahin H, Saglam R (2015) A research about microwave effects on the weed plants. J Agr Biol Sci 10:79-84

Schmid B, Puttick GM, Burgess KH, Bazzaz FA (1988) Correlations between genet architecture and some life history features in three species of Solidago. Oecologia 75:459464

Speir TW, Cowling JC, Sparling GP, Westaw, Corderoy DM (1986) Effects of microwave radiation on the microbial biomass, phosphatase activity and levels of extractable $\mathrm{N}$ and $\mathrm{P}$ in a low fertility soil under pasture. Soil Biol Bioch 18:377-382

Symon D, Haegi L (1991) Datura (Solanaceae) is a new world genus. Pages 197-210 in Nee M., Symon, D., Lester, RN, Jessop J, eds. Solanaceae IV: Advances in Biology and Utilization. Royal Botanic Gardens, Kew

Van Kleunen MV, Fischer M, Johnson SD (2007) Reproductive assurance through selffertilization does not vary with population size in the alien invasive plant Datura stramonium. Oikos 116:1400-1412

Wainwright M, Killham K, Diprose MF (1980) Effects of $2450 \mathrm{MHz}$ microwave radiation on nitrification, respiration and S-oxidation in soil. Soil Biol Bioch 12:489-493

Weber E, Jakobs G (2005) Biological flora of central Europe: Solidago gigantea Aiton. Flora 200:109-118

Wolkovich EM, Cleland EE (2011) The phenology of plant invasions: a community ecology perspective. Front Ecology Environ 9:287-294 
Table 1. Results of Generalized Linear Models testing the effect of microwave treatment, depth and species and their interactions on germination percentage (logistic regression).

\begin{tabular}{llll}
\hline Factors & $d f$ & Wald statistic $\left(\chi^{2}\right)$ & $P$ \\
\hline Microwave treatment & 7 & 1013.36 & $<\mathbf{0 . 0 0 1}$ \\
Depth & 1 & 3.50 & 0.061 \\
Species & 2 & 37.12 & $<\mathbf{0 . 0 0 1}$ \\
Microwave treatment $\times$ Depth & 7 & 21.22 & $\mathbf{0 . 0 0 3}$ \\
Microwave treatment $\times$ Species & 14 & 43.48 & $<\mathbf{0 . 0 0 1}$ \\
Depth $\times$ Species & 2 & 2.44 & 0.294 \\
Microwave treatment $\times$ Depth $\times$ Species & 14 & 24.78 & $\mathbf{0 . 0 3 6}$ \\
\hline
\end{tabular}

The Wald statistic used to test the significance of the parameters, degrees of freedom $(d f)$ and p values $(P)$ are indicated. Values in bold indicate significance at $P<0.05$.

Table 2. Results of Generalized Linear Models testing the effect of microwave treatment, depth, moisture and species and their interactions on germination percentage (logistic regression).

\begin{tabular}{llll}
\hline Factors & $d f$ & Wald statistic $\left(\chi^{2}\right)$ & $P$ \\
\hline Microwave treatment & 4 & 1456.57 & $<\mathbf{0 . 0 0 1}$ \\
Depth & 1 & 5.24 & $\mathbf{0 . 0 2 2}$ \\
Species & 2 & 36.57 & $<\mathbf{0 . 0 0 1}$ \\
Moisture & 2 & 455.88 & $<\mathbf{0 . 0 0 1}$ \\
Microwave treatment $\times$ Depth & 4 & 14.28 & $\mathbf{0 . 0 0 6}$ \\
Microwave treatment $\times$ Species & 8 & 96.10 & $<\mathbf{0 . 0 0 1}$ \\
Depth $\times$ Species & 2 & 7.26 & $\mathbf{0 . 0 2 6}$ \\
Depth $\times$ Moisture & 2 & 15.95 & $\mathbf{0 . 0 0 0 3}$ \\
Species $\times$ Moisture & 4 & 10.41 & $\mathbf{0 . 0 3 4}$ \\
Microwave treatment $\times$ Depth $\times$ Species & 8 & 20.67 & $\mathbf{0 . 0 0 8}$ \\
Species $\times$ Depth $\times$ Moisture & 4 & 20.54 & $<\mathbf{0 . 0 0 1}$ \\
Species $\times$ Microwave treatment $\times$ Moisture & 16 & 20.10 & 0.215 \\
Depth $\times$ Microwave treatment $\times$ Moisture & 8 & 23.59 & $\mathbf{0 . 0 0 3}$ \\
Species $\times$ Depth $\times$ Microwave treatment $\times$ Moisture & 16 & 15.08 & 0.519 \\
\hline The Wald statistic used to test the significance of the parameters, degrees of freedom $(d f)$ and \\
p values $(P)$ are indicated. Values in bold indicate significance at $P<0.05$. & \\
& & &
\end{tabular}


574 Figure 1. Germination percentage of Solidago gigantea, Fallopia $\times$ bohemica and Datura 575 stramonium in control treatment and after different power $\times$ duration microwave treatments at 576 two depths in the soil. Top: seed bags placed at $2 \mathrm{~cm}$ depth; bottom: seed bags placed at $12 \mathrm{~cm}$ depth. Values are expressed as means \pm SE of the five replicates. Letters indicate statistically significant differences (microwave treatment $\times$ depth $\times$ species interaction, post-hoc Tukey's test, $P<0.05$ ).

580

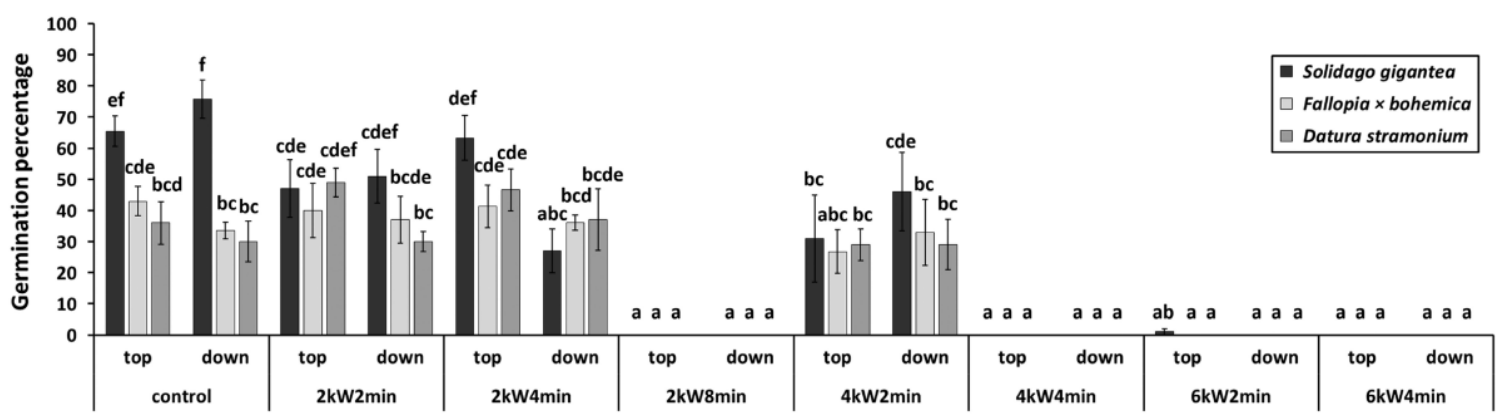


Figure 2. Germination percentage of Solidago gigantea, Fallopia $\times$ bohemica and Datura stramonium in control treatment and after different power $\times$ duration microwave treatments at two depth in the soil with three different moistures $(\mathrm{H} 1=10.2 \% \pm 2.6, \mathrm{H} 2=20.4 \% \pm 1.6, \mathrm{H} 3=$ $31.4 \% \pm 2.4$ ). Top: seed bags placed at $2 \mathrm{~cm}$ depth, bottom: seed bags placed at $12 \mathrm{~cm}$ depth. Values are expressed as means \pm SE of the five replicates. Letters indicate statistically significant differences (microwave treatment $\times$ depth $\times$ moisture interaction, post-hoc Tukey's test, $P<0.05$ ).

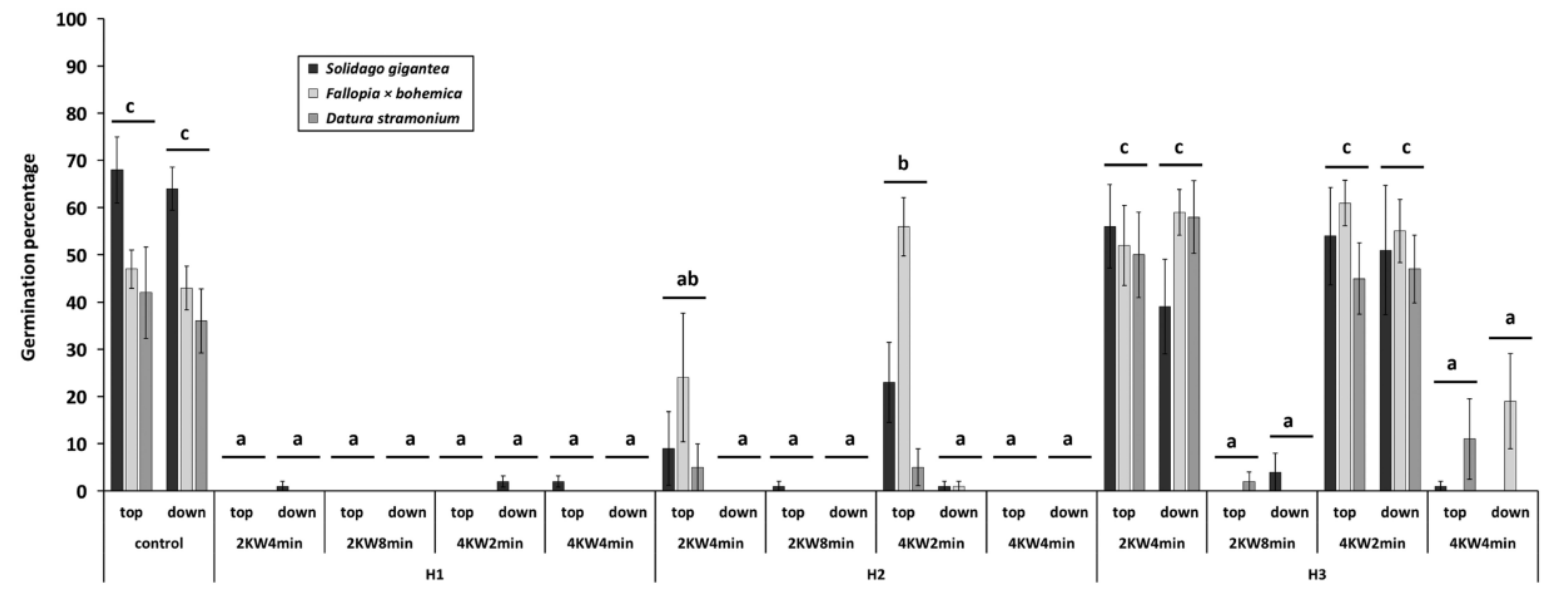

